\title{
Abundance and diversity of Bacillus thuringiensis in Bangladesh and their cry genes profile
}

\author{
Asaduzzaman Shishir, Arpita Roy, Namista Islam, Alamgir Rahman, Shakila N. Khan and \\ Md. Mozammel Hoq *
}

Laboratory-215, Department of Microbiology, University of Dhaka, Dhaka, Bangladesh

\section{Edited by: \\ Khwaja M. Sultanul Aziz, \\ Bangladesh Academy of Sciences, \\ Bangladesh}

\section{Reviewed by:}

Gulnihal Ozbay, Delaware State

University, USA

William Hsiao, University of British

Columbia, Canada

\section{*Correspondence:}

Md. Mozammel Hoq, Laboratory-

215, Department of Microbiology,

University of Dhaka, Dhaka- 1000,

Bangladesh

e-mail:mmzhoq@gmail.com
Bacillus thuringiensis $(B t)$ biopesticides, a recognized eco-friendly pest control agent, can be used to reduce many problems associated with indiscriminate use of chemical pesticides such as environmental pollutions, public health problems, emergence of resistance among pests in many developing countries etc. Bt strains were, therefore, isolated from different ecosystems of Bangladesh and characterized based on biochemical typing, 16S rRNA gene analysis, plasmid and cry genes profiles. Bt index was calculated 0.86 in this study and variations in abundance and distribution pattern of 16 different biotypes were demonstrated within 316 indigenous $B t$ strains which was compared to the other parts of the world. Bt indiana (17.8\%), Bt kurstaki (16.7\%), and Bt thuringiensis $(12.7 \%)$ were found to be the most prevalent in Bangladesh among other biotypes. Hemolytic activity was variable among the biotypes and it was maximum for $B t$ biotype 10 (100\%). Plasmids in the biotypes indiana, kurstaki, thuringiensis, and israelensis were observed to occupy a wider range than other biotypes. The screening for insecticidal genes viz. cry1, cry2, cry3, cry $4 A$, cry8, cry9, cry10, and cry 11 in the native Bt strains revealed their presence in varied proportion rendering cry 1 , cry2, and cry3 the most abundant. The abundance of $B t$ strains, their diversities and the cry genes profile were thus analyzed in this study which will be the basis for further research development with $B t$ biopesticide in Bangladesh.

Keywords: public health, Bacillus thuringiensis, biotyping, abundance and diversity, cry genes

\section{INTRODUCTION}

Pesticides are poisonous chemicals designed to impair the immune, reproductive, or nervous system of insects and killing thereby to protect agricultural and industrial products. Since an ideal pesticide must be lethal to the targeted pests, not to the non-target species including human, most of the chemical pesticide do not fall into this category because a wide range of acute and chronic human health problems, unfortunately, are linked to the chemical pesticides. Acute health effects appear shortly after the exposure to these pesticides such as skin and eye irritations, headaches, dizziness and nausea, weakness, breathing difficulty, mental confusion and disorientation, seizures, coma, and even death. Chronic health effects normally appear months or years after the exposure even at minimal level in the environment or from the ingested food and water contaminated with pesticide residues. These include disorders with nervous, reproductive or immune system and cancer as well (Aktar et al., 2009).

The high risk groups exposed to pesticides include production workers, formulators, sprayers, mixers, loaders, and agricultural farm workers. The epidemiological evidences suggest significantly higher rate of cancer incidences among farmers and farm workers in the US and Europe than among non-farm workers in some areas (Cantor et al., 1992). There are strong evidences for associations between lymphomas and soft-tissue sarcomas and certain herbicides (Zahm et al., 1990) as well as between lung cancer and exposure to organochlorine insecticides (Pesatori et al., 1994) in these high-risk populations. The annual occurrence of worldwide pesticide poisonings was estimated three million which resulted in 220,000 deaths (WHO, 1992).

On the other hand, pesticides damage the agricultural land firstly by harming beneficial insect species, soil microorganisms and worms which naturally limit pest populations and maintain soil health, secondly by weakening plant root systems and immune systems and finally reducing concentrations of essential plant nutrients in the soil such as nitrogen and phosphorous (The toxic action centre, 2012).

The consumption of chemical pesticides in Bangladesh has increased from 7350 metric tons in 1992-16,200 metric tons in 2001, more than doubling in the past decade and major chemical pesticides currently in use are, organophosphate, carbamate, pyrethroid, 2-dimethylaminopropane-1,3-dithiol, dithiocarbamate etc (Meisner and Dasgupta, 2004). A substantial body of anecdotal evidence also suggests that pesticide poisonings and ecological damage have become commonplace in Bangladesh (Jackson, 1992; Ramaswamy, 1992).

The contamination rate of pesticide is undoubtedly higher for fruits and vegetables because these foods receive the highest dosage of pesticides. In fact, it has been shown in a study performed by USDA that some pesticide residue remains in fruits 
and vegetables even after they have been washed, peeled, or cored (Wiles and Campbell, 1994).

So, alternatives of chemical pesticides remain obligatory and one of the most promising alternatives is the use of biological control agents or biopesticides from entomopathogenic microorganisms i.e., Bacillus thuringiensis $(B t)$. Bt is a gram-positive soil dwelling bacterium that synthesizes proteinaceous insecticidal crystals or $\delta$-endotoxins during sporulation which can specifically kill insects belonging to the Lepidoptera, Coleoptera, Diptera, Hymenoptera, Hemiptera, and Mallophaga as well as some invertebrates (Ben-Dov et al., 1997; Schnepf et al., 1998; Feitelson et al., 1999). It has been successfully used for last few decades for its advantages like specific toxicity against target insects, lack of polluting residues and safety to non-target organisms such as mammals, birds, amphibians and reptiles etc. It has been used in agriculture, forestry and mosquito control and accounts for $95 \%$ of the $1 \%$ market share of biopesticides in the total pesticide market (Flexner and Belnavis, 1999). Over last 15 years, the global area devoted for production of transgenic $B t$ crops has got a rapid increase to more than 69 million hectares in 2012. It has been reported that insects can evolve resistance rapidly to $B t$ crops that are not high dose and raise concerns about the adequacy of current resistance management strategies (Gassmann et al., 2014).

Hence, the scopes and applications of $B t$ are increasing with their diversities around the world. Continuous searching for more and more $B t$ with diversities, therefore, keeps utmost importance and in this connection, $B t$ was isolated from different locations of Bangladesh to analyze the abundance and diversity with respect to phenotypic and genotypic characteristics.

\section{MATERIALS AND METHODS BACTERIAL STRAINS}

Bt kurstaki HD-73, B. thuringiensis sotto, B. thuringiensis japonensis Buibui were used as reference strains and were obtained from $B t$ stock collection of Okayama University, Japan.

\section{SAMPLING AND ISOLATION OF BACILLUS THURINGIENSIS}

Samples, comprising of soil, leaf, insect cadavers and stored product dust, were collected from different locations of Bangladesh (Figure 1) where $B t$ biopesticide was not applied before and sampling sites encompassed different ecosystems such as plane land, river basin, hill tracts, sea beaches etc. Soil (about $10.0 \mathrm{~g}$ each) samples were collected from 2 to $5 \mathrm{~cm}$ below the surface of shadowed and slightly moistened places, generally not exposed to sunlight with sanitized spatula into the sterile plastic bags to avoid contamination. Leaves, insects and stored dust products were also collected aseptically. Samples were kept at room temperature in an assigned dry place of laboratory. Then $1.0 \mathrm{~g}$ of each soil sample (for leaf, 1 piece in each flask and for each insect, gut was dissected out, crushed and mixed into the medium) was added in a $125 \mathrm{ml}$ Erlenmeyer flask containing $20 \mathrm{ml}$ of L- broth (per liter: tryptone $10.0 \mathrm{~g}$, yeast extract $5.0 \mathrm{~g}, \mathrm{NaCl} 5.0 \mathrm{~g}$ ) supplemented with $0.25 \mathrm{M} \mathrm{Na}$-acetate ( $\mathrm{pH} 6.8$ ) and incubated in an orbital shaker at $30^{\circ} \mathrm{C}$ and $200 \mathrm{rpm}$. After $4 \mathrm{~h}, 0.5 \mathrm{ml}$ of suspension was transferred into a sterile test tube and heat treated for $10 \mathrm{~min}$ at $80^{\circ} \mathrm{C}$ in a water bath. Heat treated suspension was then diluted 10 -folds and $0.1 \mathrm{ml}$ was inoculated onto $\mathrm{T}_{3}$ - agar medium (1.0 L: Tryptone $3.0 \mathrm{~g}$, tryptose $2.0 \mathrm{~g}$, yeast extract $1.5 \mathrm{~g}, \mathrm{MnCl}_{2} 0.005 \mathrm{~g}$, phosphate buffer $50 \mathrm{mM}$, agar $15.0 \mathrm{~g}$; pH: 6.8) (Travers et al., 1987) by spread plate method and incubated at $30^{\circ} \mathrm{C}$. In case of appearance of any colony after overnight incubation, incubation period was extended up to $72 \mathrm{~h}$ to allow sporulation. Colonies were then picked and dispersed in sterile distilled water and examined with Phase Contrast Microscope. Colonies comprising of isolates with juxtaposed glowing spore and dark crystal protein as revealed under Phase Contrast Microscope (Primostar, Zeiss, Germany) were considered as $B t$ or Bacillus sphaericus. To distinguish $B t$ from $B s$, starch hydrolysis test was performed according to the Bergey's Manual of Determinative Bacteriology and isolates with starch hydrolysing ability were identified as Bt. The diameter of spores was measured using the software ZEN (Zeiss, Germany).

\section{HEMOLYTIC TEST}

Hemolytic test was performed to identify $B t$ isolates producing broad-spectrum cytolysins. Bt isolates were therefore inoculated (as dots with needle) onto Blood agar medium (nutrient agar containing $5 \%(\mathrm{v} / \mathrm{v})$ sheep erythrocytes) and incubated overnight at $27^{\circ} \mathrm{C}$. Isolates forming clear zone of hemolysis around their colonies were considered as hemolytic (Ichikawa et al., 2008).

\section{BIOCHEMICAL TYPING}

Four most relevant biochemical tests i.e., esculin utilization, acid formation from salicin and sucrose, and lecithinase production were carried out to classify Bt into 16 biotypes (Martin and Travers, 1989).

\section{TOTAL DNA PREPARATION}

Total DNA was prepared from the single colonies of indigenous $B t$ isolates obtained after incubation by streaking on LB agar medium (Bravo et al., 1998). After $12 \mathrm{~h}$ of incubation at $30^{\circ} \mathrm{C}$, a single colony was transferred into $100 \mu \mathrm{l}$ sterile de-ionized water in a microfuge tube, vortexed and kept for $20 \mathrm{~min}$ at $-70^{\circ} \mathrm{C}$. It was then incubated in boiling water for $10 \mathrm{~min}$ to lyse the cells and briefly centrifuged for $20 \mathrm{~s}$ at $12,000 \times \mathrm{g}$. The upper aqueous phase transferred into sterile microfuge tubes was used as template and preserved at $-20^{\circ} \mathrm{C}$ for further use. Fifty to Hundred nanograms of DNA from this suspension was used as template in PCR.

\section{S rRNA GENE ANALYSIS}

PCR amplification of 16S rRNA gene from indigenous $B t$ isolates was performed with universal primers for Bacillus spp.: fwd (20F); 5'-GAGTTTGATCCTGGCTCAG-3' (position 9-27), and rev (1500R); 5'-GTTACCTTGTTACGACTT-3' (position 14921509). The PCR was performed in a thermal cycler (MJ, Bio-Rad) by 35 cycles $\left(96^{\circ} \mathrm{C}\right.$ for $50 \mathrm{~s}, 50^{\circ} \mathrm{C}$ for $45 \mathrm{~s}, 72^{\circ} \mathrm{C}$ for $2 \mathrm{~min}$ ) with an initial denaturation step at $96^{\circ} \mathrm{C}$ for $10 \mathrm{~min}$ and a final extension step at $72^{\circ} \mathrm{C}$ for $10 \mathrm{~min}$ in $25 \mu \mathrm{l}$ reaction mixture (forward and reverse primers $0.5 \mu \mathrm{M}$ each, $50-100 \mathrm{ng}$ of template, $0.5 \mathrm{U}$ of Taq DNA polymerase (Promega, USA), $200 \mu \mathrm{M}$ dNTPs, $10 \mathrm{mM}$ Tris, $50 \mathrm{mM} \mathrm{KCl}$ and $1.5 \mathrm{mM} \mathrm{MgCl}_{2}$ ).

PCR product $(5 \mu \mathrm{l})$ was analyzed in $1 \%(\mathrm{w} / \mathrm{v})$ Agarose (Promega, USA) gel electrophoresis at $60 \mathrm{~V}$ for $1 \mathrm{~h}$ in $1 \times \mathrm{TBE}$ buffer and visualized against UV trans-illumination in a gel 


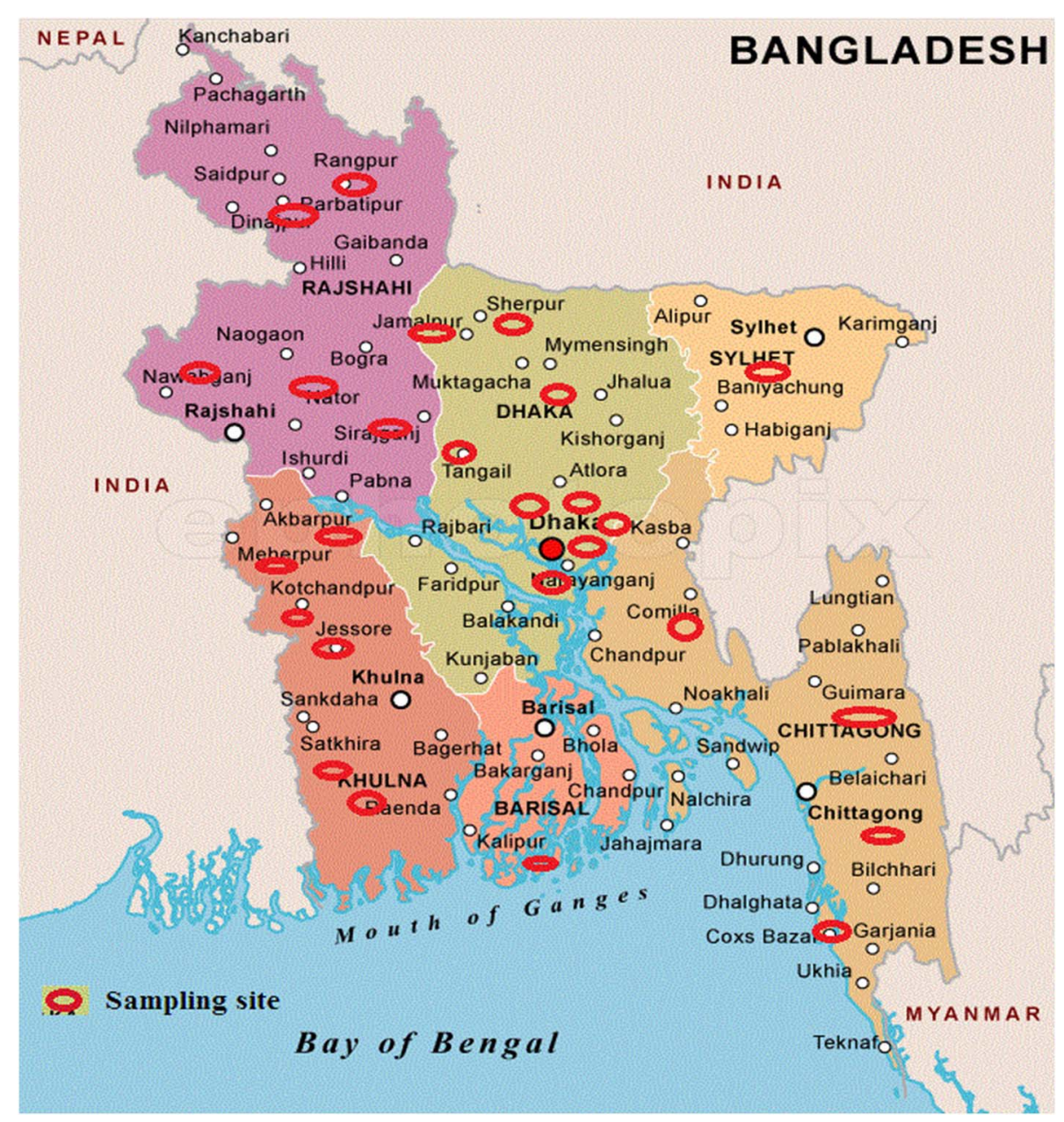

FIGURE 1 | Sampling sites to isolate Bacillus thuringiensis from Bangladesh. Sampling sites are indicated by red eclipses over the map.

documentation system (Alpha imager mini, USA) following staining in EtBr (Sigma, USA) solution $(0.5 \mu \mathrm{g} / \mathrm{ml})$ and destaining in distilled water. Purified PCR products (Wizard ${ }^{\circledR}$ SV Gel and PCR Clean-Up System, Promega, USA) were sequenced at CARS, University of Dhaka, Bangladesh and the sequences were submitted in the NCBI database (Table 3).

\section{PLASMID PROFILING}

Plasmid DNA was prepared by using the alkaline lysis method (Crosa and Falkow, 1981). Briefly, the pellet of a $5.0 \mathrm{ml}$ culture grown in LB broth was lysed with $0.85 \mathrm{ml}$ of TE buffer (50 mM Tris, $20 \mathrm{mM}$ EDTA; $\mathrm{pH} 8.5$ ) containing $2.0 \mathrm{mg} / \mathrm{ml}$ of lysozyme (Wako, Japan), $0.05 \mathrm{ml}$ of $20 \%$ SDS solution, and $5.0 \mathrm{U}$ proteinase-K (Nacalai tesque, inc, Japan). After mixing by gentle inversions, the cell suspension was incubated at $37^{\circ} \mathrm{C}$ for $30 \mathrm{~min}$. $0.03 \mathrm{ml}$ of $3.0 \mathrm{~N} \mathrm{NaOH}$ was added subsequently to the suspension and mixed gently for $3 \mathrm{~min}$. The suspension was neutralized by addition of $0.06 \mathrm{ml}$ of $2.0 \mathrm{M}$ Tris- $\mathrm{HCl}$ ( $\mathrm{pH} 7.0$ ) and mixed gently. Then $0.1 \mathrm{ml}$ of $5.0 \mathrm{M} \mathrm{NaCl}$ was added, and the suspension was mixed by inversions, placed on ice for $15 \mathrm{~min}$, and then centrifuged at $12,000 \times \mathrm{g}$ for $15 \mathrm{~min}$ at $4^{\circ} \mathrm{C}$ (Tomy, MX-305, high speed Refrigerated micro centrifuge, Japan). The supernatant was transferred into a fresh centrifuge tube, and 2 volume of ice-cold ethanol was added. The tube was kept at $-20^{\circ} \mathrm{C}$ for $15 \mathrm{~min}$ and then centrifuged at $12,000 \times \mathrm{g}$ for $15 \mathrm{~min}$. The supernatant was discarded, and the residue was dried by inverting the tube over a paper towel for a few minutes. The residue was dissolved in $50 \mu \mathrm{l}$ of TE buffer ( $10 \mathrm{mM}$ Tris, $1 \mathrm{mM}$ EDTA) and kept at $-20^{\circ} \mathrm{C}$. Plasmid DNA was analyzed by electrophoresis on horizontal $0.8 \%$ agarose (Promega, USA) gel submerged in $1 \times \mathrm{TBE}$ buffer at $70 \mathrm{~V}$ for $3 \mathrm{~h}$. Gel was visualized in a gel documentation system following staining and de-staining.

\section{OLIGONUCLEOTIDE PRIMERS FOR PCR}

Previously described primers for $\operatorname{cry} 1, \operatorname{cry} 4 A, \operatorname{cry} 8, \operatorname{cr} y 10$, and cry 11 genes were used in this study (Table 1) whereas the primers for $\operatorname{cry} 2, \operatorname{cry} 3$, and $\operatorname{cry} 9$ genes were designed with the help of Primer-BLAST program from the conserved regions of respective gene sequences obtained from NCBI database.

\section{DETECTION OF cry GENES}

DNA templates from $B t$ strains were mixed with PCR reaction mixture i.e., per $\mu \mathrm{l}$ containing $0.2 \mathrm{mM}$ dNTPs, $0.5 \mu \mathrm{M}$ of each primer, $1 \times \mathrm{PCR}$ buffer and $0.5 \mathrm{U}$ of Taq DNA polymerase 
Table 1 | Properties of the primers used in the detection of cry genes.

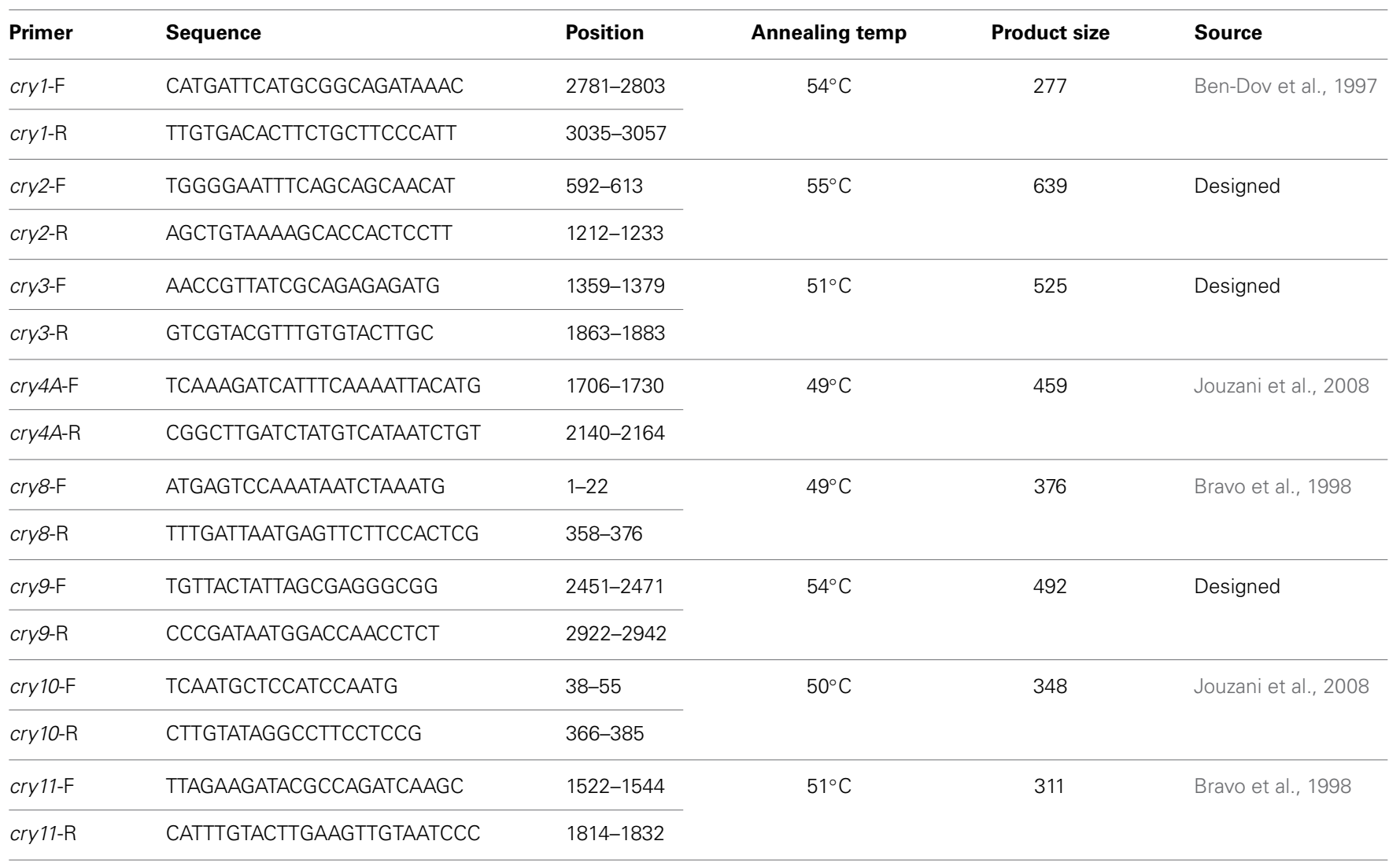

(Promega, USA) in $25 \mu \mathrm{l}$ reaction volume and amplification was performed in a DNA thermal cycler (MJ, Bio-Rad). For all primer sets, PCR was carried out with an initial single denaturation step at $95^{\circ} \mathrm{C}$ for $2 \mathrm{~min}$ and 30 amplification cycles including denaturation at $95^{\circ} \mathrm{C}$ for $45 \mathrm{~s}$, annealing at temperatures specific for each primer sets (Table 1) for $45 \mathrm{~s}$ and extension at $72^{\circ} \mathrm{C}$ for $60 \mathrm{~s}$. Finally an extra extension step was applied at $72^{\circ} \mathrm{C}$ for $10 \mathrm{~min}$. PCR products $(10 \mu \mathrm{l})$ were then electrophoresed in $1.5 \%$ agarose (Promega, USA) gel prepared and submerged in $1 \times$ TBE buffer at $60 \mathrm{~V}$ for $60 \mathrm{~min}$. Gel was visualized in a gel documentation system following staining and de-staining.

\section{RESULTS}

\section{DISTRIBUTION OF BACILLUS THURINGIENSIS}

Total 231 samples from 26 districts encompassing 6 different regions of Bangladesh (Figure 1) were processed and after acetate selection and heat treatment, 366 isolates were found to synthesis crystal protein during sporulation by Phase Contrast Microscopy (Figure 2). Among them, 317 isolates were distinguished as Bt for their starch hydrolysing capability and rest of them were considered Bacillus sphaericus. The distribution analysis of Bt in Bangladesh (Table 2) indicates that almost all parts of Bangladesh are rich in $B t$ as the average $B t$ index was calculated 0.86 . Bt was most abundant in the Northern and Central part (index 0.90 and 0.89 respectively) and the least abundant was in the sandy beach (index-0.73) (Table 2).
The spore diameters of indigenous $B t$ from Bangladesh were observed to be in the range of $0.6-1.02 \mu \mathrm{m}$ and the average spore diameter was calculated to be $0.76 \pm 0.097 \mu \mathrm{m}$ whereas it was $0.63 \pm 0.081 \mu \mathrm{m}$ for reference Btk HD-73 in this study.

\section{PREVALENCE OF BIOTYPES}

Biochemical typing helped in classification of indigenous $B t$ strains into 16 biotypes. From this study, B. thuringiensis indiana (17.8\%), kurstaki (16.7\%), thuringiensis (12.7\%) etc. biotypes were found to be the most prevalent in Bangladesh (Figure 3). Bt biotypes 11 , sotto, 9, 13 and israelensis were almost equal in their abundances ( $5 \%$ of total).

The distribution of different biotypes in different sampling sites was also analyzed. The distribution pattern implies that almost all biotypes are present in the sampling sites in an unbiased manner except few. Bt thuringiensis found to be abundant in the central zone of Bangladesh and $B t$ kurstaki was abundant in Jhenidah. However, the distribution pattern of $B t$ biotypes seemed unique when compared with the rest of the world (Figure 3). Bt thuringiensis, kurstaki and indiana together account for $47 \%$ of the total isolates of Bangladesh whereas it is $0,30,4.4,6.9,4.6$, and $12 \%$ for New Zealand, other countries of Asia, Europe, Africa, Central \& South America and United States respectively (Martin and Travers, 1989). Abundance of Bt israelensis is low in Bangladesh whereas it is remarkable in other parts of the world. 



FIGURE 2 | Examination of Bacterial isolates from the colonies incubated up to $72 \mathrm{~h}$ to allow sporulation by Phase contrast microscopy. Glowing spores and juxtaposed crystal protein as revealed under Phase Contrast microscope rendered them as Bacillus thuringiensis strains.

Table 2 | Distribution of Bacillus thuringiensis in different regions of Bangladesh.

\begin{tabular}{lccccc}
\hline Regions & Samples & Isolates producing crystal protein & Bt isolates & Abundant biotype & Bt index \\
\hline Central part & 86 & 148 & 133 & thu, kur, ind & ind, kur, sotto \\
Southern part & 40 & 66 & 58 & Ind, 16, 11 & ind, 15 \\
Northern part & 18 & 31 & 28 & 40.87 & 0.90 \\
Hill tracts & 22 & 46 & 40 & 0.86 \\
River basin & 60 & 57 & 10 & 11 & thu, kur, 16 \\
Sandy beach & 5 & 18 & 317 & ind, kur, thu, 11 \\
\hline Total & 231 & 366 & 0.82 \\
\hline
\end{tabular}

The Bt index was calculated as a number of Bt isolates recovered divided by the number of colonies examined. thu, Bt thuringiensis; kur, Bt kurstaki; ind, Bt Indiana; $10,11,16$, other biotypes of Bt which do not describe any subspecies yet.

\section{BROAD SPECTRUM CYTOLYSIN ACTIVITY}

Three hundred and seventeen $B t$ strains were tested for broad spectrum cytolysin activity and $58.36 \%$ (189) of them were found to have this property hence presumed as insecticidal and rest $41.64 \%$ can be explored for anti-cancer cell protein, parasporin. Based on this property, percentages of insecticidal strains in each biotype were also determined (Figure 4). The order of percentage of insecticidal strains was thus made- $B t 10>B t$ kurstaki $>B t$ dendrolimus $>B t$ thuringiensis $>B t 9>B t$ indiana $>$ Bt israelensis.

\section{S rRNA GENE SEQUENCE ANALYSIS}

Amplicons of about 1500 bp were obtained from PCR amplification of $16 \mathrm{~S}$ rRNA gene of indigenous $B t$ isolates (Figure 5). The sequences obtained from the amplicons were used for nucleotide blast in NCBI database (http://www.ncbi.nlm.nih.gov/) and the sequences producing significant alignments to them with more than $96 \%$ identity were observed to be from different strains of Bt. GenBank Accession numbers for these strains are provided (Table 3).

\section{DIVERSITY IN PLASMID PROFILE}

Diversity was observed in the plasmid profiles of indigenous $B t$ strains. Clearly visible supercoiled plasmids were present in the range of $3 \mathrm{~kb}$ to more than $16 \mathrm{~kb}$. $81 \%$ of the visible plasmid bands fall into the range of 10-13 kb (Figure 6). The pattern for small plasmids was compared and molecular weight based distribution of plasmids among the biotypes was determined which in other sense renders the diversity too. Plasmids in Bt thuringiensis, kurstaki, indiana, and israelensis exhibited more diversity as the plasmids from these biotypes were present in the range of 3 to more than $16 \mathrm{~kb}$ (Figure 7).

\section{cry GENE PROFILE}

Upon electrophoresis of PCR products in 1.5\% Agarose gel, amplicons for the target sequences of cry1, cry2, cry3, cry $4 A$, cry8, cry 9 , and $c r y 10$ genes were observed in the native $B t$ strains (Figure 8). Bt strains that produced amplicons of desired sizes (Table 1), were considered positive for respective genes. The abundances of targeted cry genes in the Bt of Bangladesh were calculated (Figure 9) and cryl gene was the most abundant with (30.8\%) followed by cry $2(25.5 \%)$, cry3 $(22.2 \%)$, and $\operatorname{cry} 9(7.2 \%)$ genes. Abundance of cry $4 A$ and $c r y 10$ genes were less than $5 \%$ and no strains with cry11 gene was found.

\section{DISCUSSION}

Continuous searching for $B t$ strains expressing toxins with novel and diverse activity keeps tremendous importance for replacing the prevailing chemical pesticides as well as to fight the pest resistance. The research was, therefore, carried out with a view to develop a $B t$ collection source characterized with their genetic and toxic properties leading to biopesticide production.

Sample was hence collected with the objectives of deducing the abundance, distribution and diversity of $B t$ in different ecosystems of Bangladesh and the cry gene profiles. Sampling was 


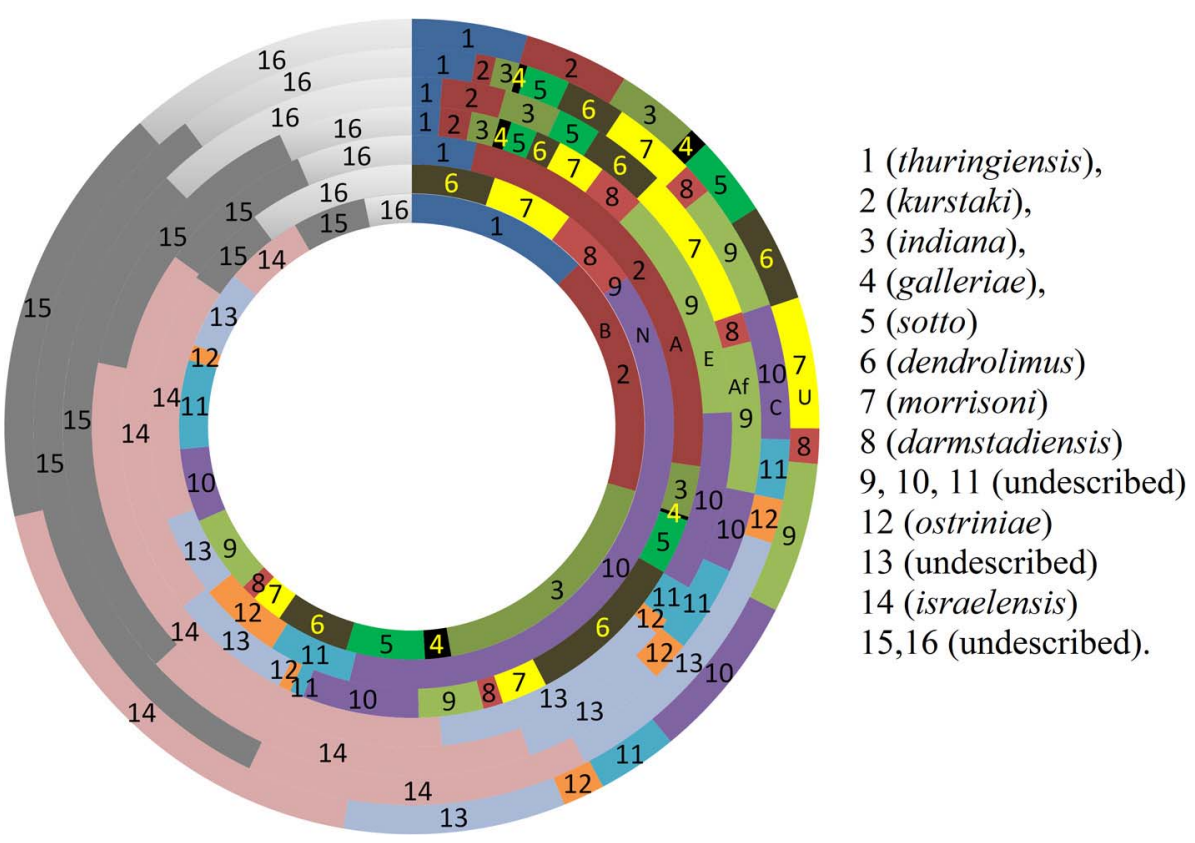

FIGURE 3 | Comparison of prevalence (\%) pattern of different biotypes around the world. (Rings from centre to periphery: B, Bangladesh; N, New Zealand; A, Asia; E, Europe; Af, Africa; C, Central and South America; U, United States).

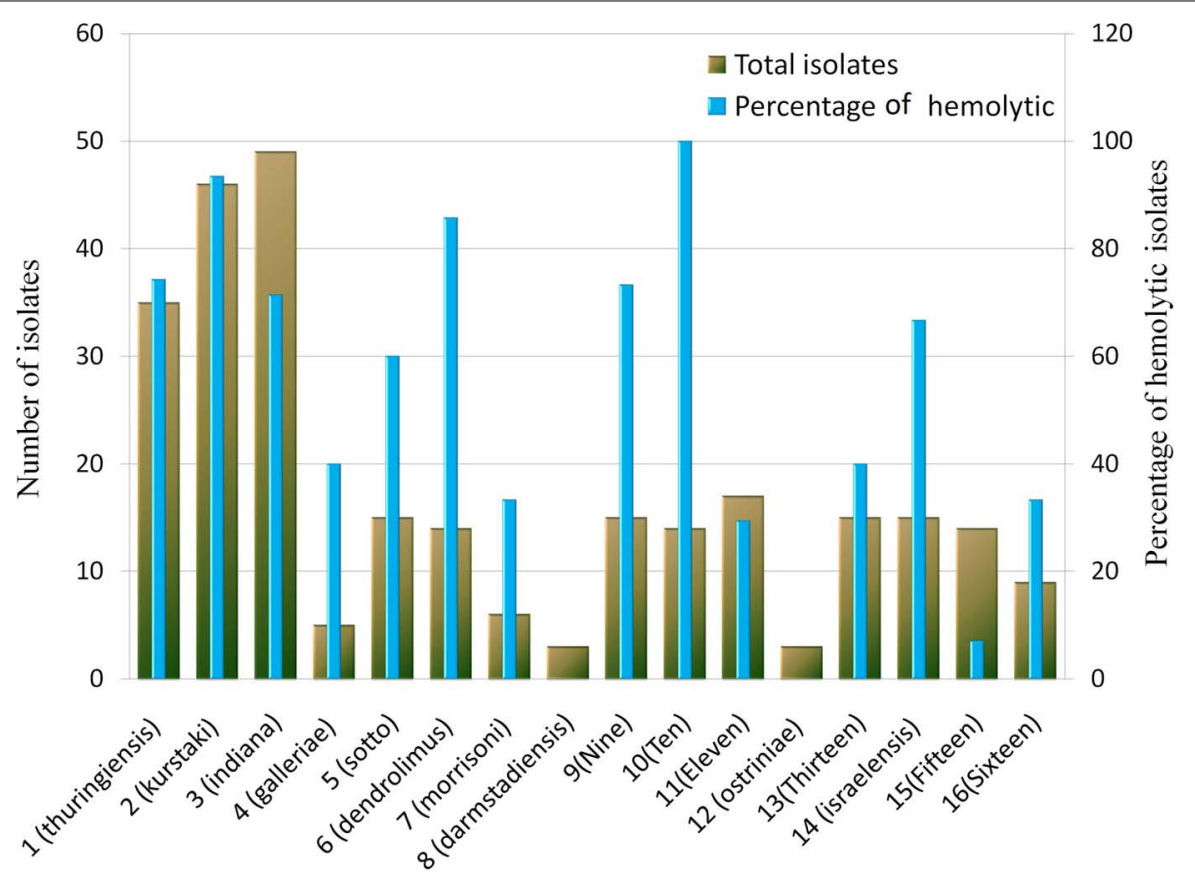

Bacillus thuringiensis biotypes

FIGURE 4 | Distribution of hemolytic Bacillus thuringiensis strains in different biotypes. Figure shows the number of isolate and the percentage of isolates with Broad spectrum cytolytic activity in each biotype which was determined by Hemolytic test.

performed from 26 different districts of Bangladesh that covered plane lands, river basin, hilly regions, sandy beaches and agricultural lands (Figure 1). Two hundred and thirty one samples were processed with acetate selection and heat treatment so that the spores other than $B t$ are germinated and heat-killed. Then the left alone $B t$ spores were allowed to germinate in $\mathrm{T}_{3}$ - agar medium for overnight which was extended up to $72 \mathrm{~h}$ for sporulation as crystal proteins are synthesized during this period. Phase 


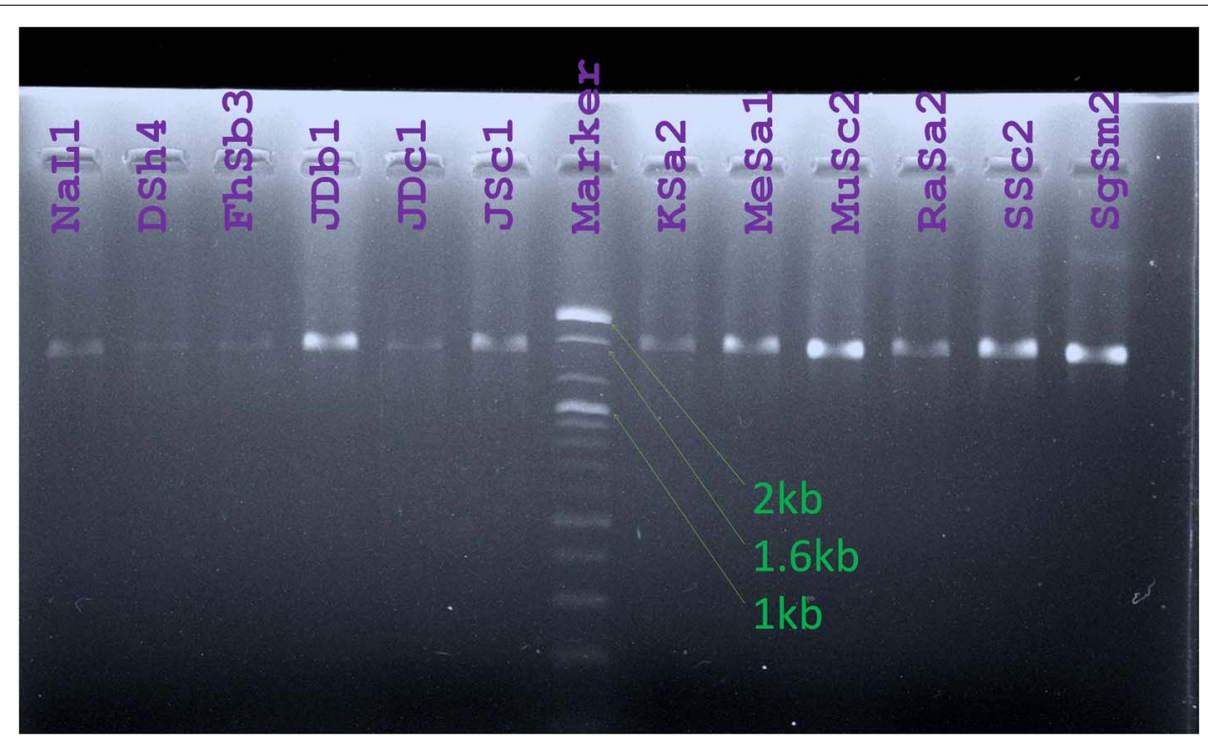

FIGURE 5 | Amplicons obtained from PCR for 16S rRNA gene amplification were visualized against UV light after Agarose gel electrophoresis. Lanes were labeled with the names of Bt strains studied. (Marker: 100 bp DNA ladder, Bioneer, Korea).

Table 3 | Sequence similarity search (BLASTn) results for 16S rRNA genes from indigenous Bt strains.



contrast microscopy was performed to identify the isolates producing crystal proteins (Figure 2) which produced 366 isolates with this property.

It was discussed that Bacillus sphaericus responded similarly in this isolation process but was distinguished by Phase contrast microscopy as lacking parasporal crystal proteins (Travers et al., 1987). Again some strains of Bacillus sphaericus synthesize a parasporal inclusion or crystal which contains proteins toxic against the larvae of a variety of mosquito species (Baumann et al., 1991). So these ambiguities should be resolved for confident discrimination of Bt from Bs. According to the Bergey's Manual of Determinative Bacteriology B. thuringiensis can be distinguished from B. sphaericus by starch hydrolysis test and this test was performed in this study. Isolates with starch hydrolyzing ability were identified as Bt. Upon starch hydrolysis test, 317 out of 366 parasporal crystal protein synthesizing isolates were confirmed as Bt.

The spore diameter of native $B t$ strains ranged from 0.6 to $1.02 \mu \mathrm{m}$ and the average spore diameter was calculated $0.76 \pm 0.097 \mu \mathrm{m}$ in this study and native $B t$ spores were found
$20 \%$ bigger than the reference Btk HD-73 (0.63 $\pm 0.081 \mu \mathrm{m})$. Deviation in spore diameters up to \pm 0.097 for local $B t$ strains is a clear indication of high diversities among the strains.

$B t$ index is often used as an indication of how easily the $B t$ was isolated which was 0.86 for Bangladesh in this study. This index was variable across different ecosystem of Bangladesh. Northern and central parts of the country were indexed higher than the rest parts. $B t$ was less available in the sandy beaches, yet it was 0.73 (Table 2).

$B t$ has got diverse functions like bacteriocin, chitinase, Vip toxins, cytocidal proteins and delta endotoxin production. These functions are not common for all and to sort out the strains with specific functions, classification is highly important. Serotyping and biotyping are two established methods for rapid classification into subspecies with a presumptive function.

Biotyping based on esculin and lecithinase hydrolysis as well as salicin and sucrose utilization which are the most variable among different $B t$ subspecies enabled in devising a simplified system of classification into 16 biochemical types (Martin and Travers, 1989). Ten out of 16 biotypes were described for known 


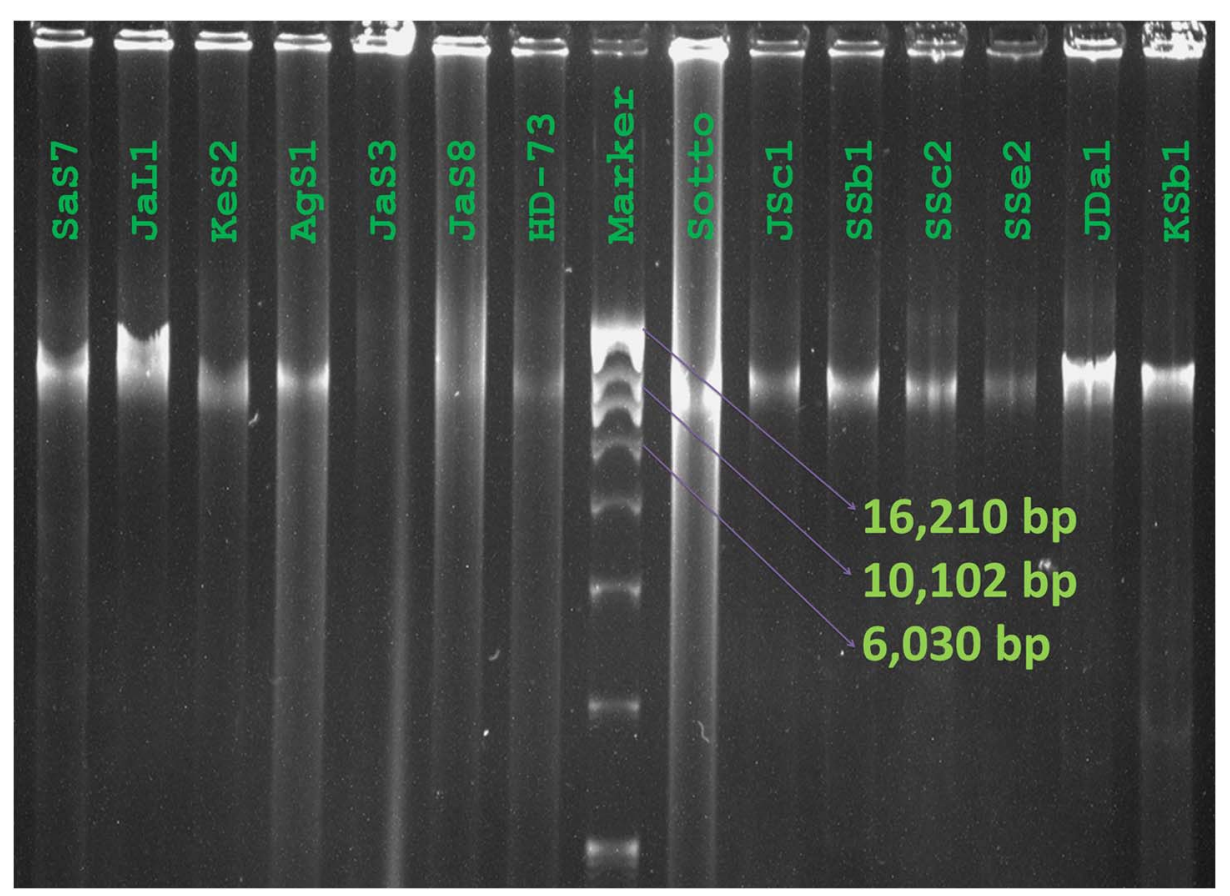

FIGURE 6 | Plasmid profiles of Bacillus thuringiensis strains of Bangladesh. Image of Plasmid DNA was captured as visualized against UV light after agarose gel electrophoresis and staining with ethidium bromide. Names of the isolates and reference strain were labeled over lanes (Marker: Supercoiled DNA ladder, Invitrogen, USA).

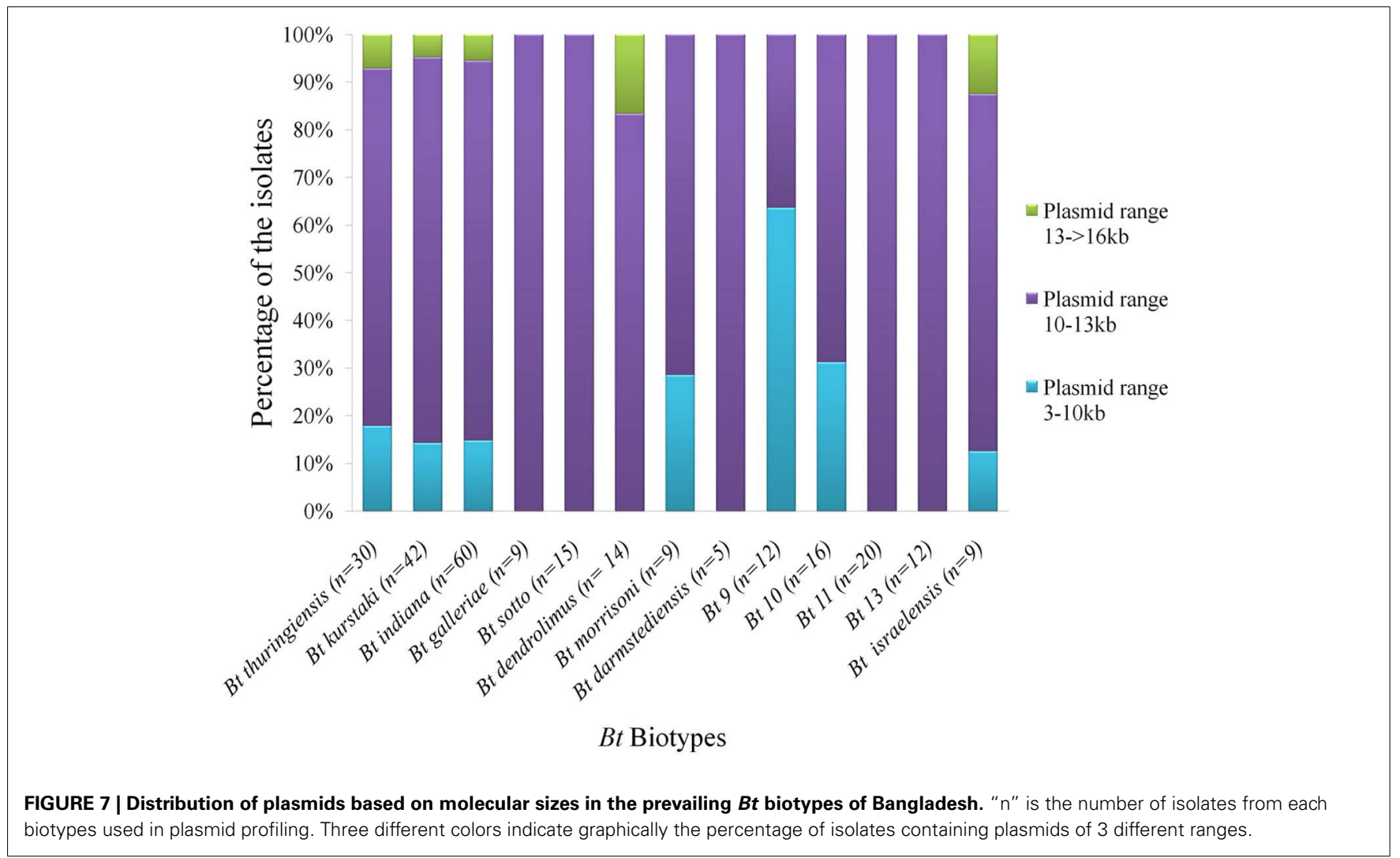



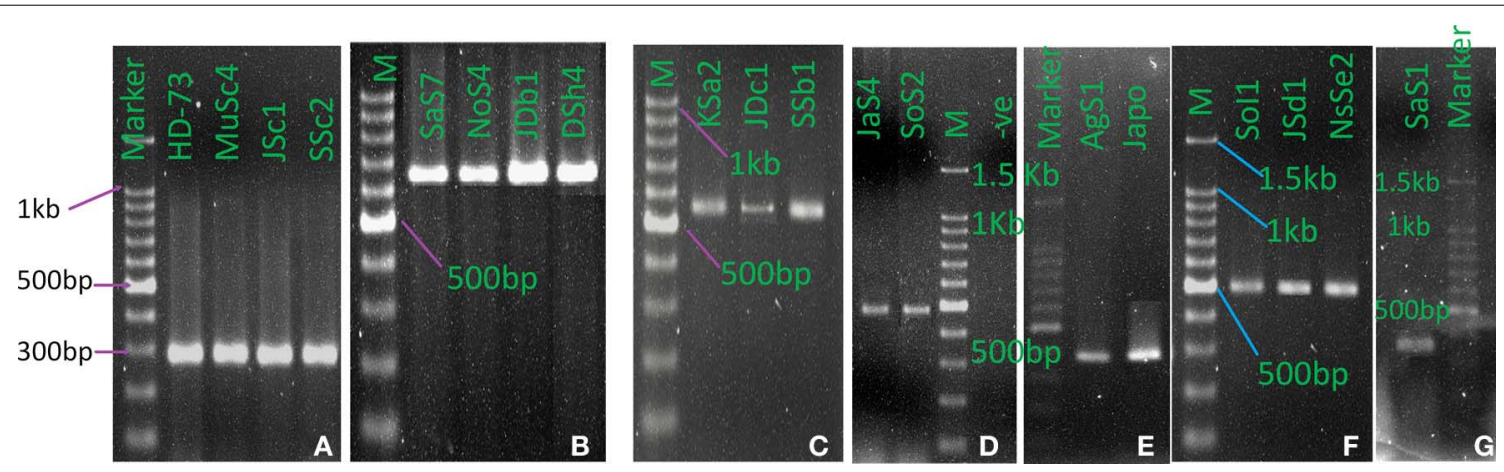

FIGURE 8 | cry genes profile of indigenous Bacillus thuringiensis. (A) cry1 (277 bp), (B). cry2 (639 bp), (C) cry3 (525 bp), (D) cry4A (459 bp), (E) cry8 (376 bp), (F) cry9 (492 bp), (G) cry10 (348 bp). (M: 100 bp DNA Marker, Takara, Japan. HD-73: B. thuringiensis kurstaki HD-73, japo: Bt japonensis Buibui).

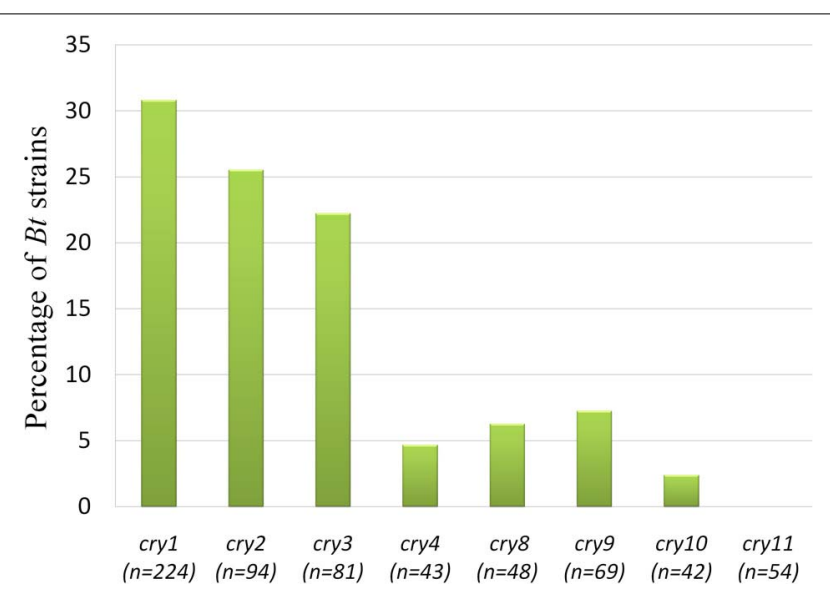

FIGURE 9 | Prevalence rate of cry genes in the Bacillus thuringiensis strains of Bangladesh. " $n$ " indicates the number of isolates tested for that particular gene. " $n$ " was determined as subspecies and/or biotype based analysis of cry genes were performed.

subspecies and in this study, further characterization and analysis were performed based on the classification. Biochemical tests results of this study estimated biotypes describing Bt indiana, kurstki, and thuringiensis as the most prevalent in Bangladesh.

The abundance of $B t$ biotypes around the world (Martin and Travers, 1989) was compared with that of Bangladesh. The abundance pattern in Bangladesh was slightly similar with that of Asian countries but high variations were discernible with other portions of the world (Figure 3). Biotypes 14 (israelensis), 15 and 16 account for $30-58 \%$ of all $B t$ strains all over the world whereas it was $13.8 \%$ for Bangladesh. On the other hand, biotype 1 (thuringiensis), 2 (kurstaki), and 3 (indiana) together account for $47.2 \%$ of all $B t$ strains in Bangladesh while only $4.4-12 \%$ was observed in the other parts of the world. For Asian countries, it accounts up to $30 \%$. Martin and Travers showed that biotypes not yet described represented $51.9 \%$ of the total isolates worldwide (Martin and Travers, 1989). It was calculated 30.5\% For Bangladesh in this study.

Again, hemolytic activity or broad spectrum cytolysin activity for presumptive identification of insecticidal isolates was performed with all the $B t$ isolates obtained. Our previous observation for strains with hemolytic activity was modified from 58.36 to $77.7 \%$ as the sampling sites and isolates increased in number (Shishir et al., 2012). The percentage of hemolytic strains in each biotype was calculated. It was found that biotype darmstadiensis and ostriniae possess no hemolytic strains and only $7 \%$ of the strains were hemolytic in biotype 15 . Less than $40 \%$ hemolytic strains were present in biotypes galleriae, morrisoni, 11, 13, 16 and more than $60 \%$ hemolytic strains were present in rest of the biotypes (Figure 4). 100\% strains from Bt 10, 93\% from kurstaki and $85 \%$ from dendrolimus were hemolytic. No such relationship was observed between percentage of hemolytic strains and abundance of cry genes in a certain biotype (Data not shown).

Then 16S rRNA gene sequencing was performed with randomly selected 19 strains and 1 reference strains. Sequences obtained following PCR with universal primer set for Bacillus were analyzed and they were identified as $B t$ by blastn program. It was performed in order to evaluating the isolation process of $B t$ by acetate selection and starch hydrolysis method.

Usually mega plasmids are present in low copy numbers and small or cryptic plasmids are present in high copy numbers in Bt. So it is likely to observe more small plasmids than mega plasmids in agarose gel electrophoresis. Again depending on the variation in techniques, successful extraction of small plasmids may vary also. Plasmid was therefore extracted with a view to compare their pattern among indigenous $B t$ strains. In our study, large plasmids were observed in many strains but due to their presence in low copy numbers, the bands were not intense enough. So the small plasmid pattern was compared and molecular weight based distribution of plasmids among the biotypes was determined which in other sense renders the diversity within the biotypes (Figure 7).

From the full list of $\delta$-endotoxins, correlation between the subspecies and cry genes was observed (Crickmore et al., 2012). Based on the information, subspecies based investigation of cry1, cry2, cry $3, \operatorname{cr} y 4 A, \operatorname{cr} y 8, \operatorname{cr} y 9, \operatorname{cr} y 10$, and $\operatorname{cr} y 11$ genes was performed into the indigenous $B t$ strains. Both expected and spurious bands were observed and the $B t$ strains with desired amplicons of about 277, $639,525,459,376,492$, and 348 bp for cry1, cry2, cry3, cry $4 A$, cry8, cry9, and cry10 genes respectively were considered as positive. Spurious products are actually generated if mismatch in priming occurs which enhances the getting of putative novel cry 
genes as reported in many studies (Jouzani et al., 2008; Bozlağan et al., 2010).

Total $73 B t$ strains out of 230 were positive for eight different cry genes examined. The number of $B t$ strains containing cry 1 gene was the maximum (69) as compared to cry2 (24), cry3 (18), $\operatorname{cry} 4 A(2), \operatorname{cry} 8(3), \operatorname{cry} 9(5)$, and cry10 (1) genes (Figure 9). Bravo et al. (1998) have found $c r y 1$ genes the most frequent (49.5\%), then cry3 gene as highly abundant $(21.7 \%)$ and cry9 gene as less abundant $(2.6 \%)$. These results showed both similarity and dissimilarity across different geographic regions which might affect the diversity of cry gene content of $B t$ strains. In addition, it is probable that the remaining 158 isolates of this study producing no amplicons for the $c r y$ genes examined may contain other genes as 72 different cry gene groups and many subgroups have been defined in the literature to date (Crickmore et al., 2012).

\section{ACKNOWLEDGMENTS}

This work was supported by a Grant-in-Aid from the USDA as a project entitled "Production of Bacillus thuringiensis biopesticides by biotechnological approach for the control of vegetable pests in Bangladesh.” We thank Okayama University, Japan for providing references strains. We also thank CARS, University of Dhaka, Dhaka-1000, Bangladesh for providing sequencing facility.

\section{REFERENCES}

Aktar, M. W., Gupta, D. S., and Chowdhury, A. (2009). Impact of pesticides use in agriculture: their benefits and hazards. Interdiscip. Toxicol. 2, 1-12. doi: 10.2478/v10102-009-0001-7

Baumann, P., Clark, M. A., Baumann, L., and Broadwell, A. H., (1991). Bacillus sphaericus as a mosquito pathogen: properties of the organism and its toxins. Microbiol. Mol. Biol. Rev. 55, 425-436.

Ben-Dov, E. A., Zaritsky, E., Dahan, Z., Barak, R., Sinai, R., Manasherob, A., et al. (1997). Extended screening by PCR for seven cry-group genes from field-collected strains of Bacillus thuringiensis. Appl. Environ. Microbiol. 63, 4883-4890.

Bozlağan, I., Ayvaz, A. R., Ozturk, F., Acik, L., Akbulut, M., and Yilmaz, S. (2010). Detection of the cry1 gene in Bacillus thuringiensis isolates from agricultural fields and their bioactivity against two stored product moth larvae. Turk. J. Agric. For. 34, 145-154. doi: 10.3906/tar-0905-19

Bravo, A., Sarabia, S., Lopez, L., Ontiveros, H., Abarca, C., Ortiz, A., et al. (1998). Characterization of cry genes in a Mexican Bacillus thuringiensis strain collection. Appl. Environ. Microbiol. 64, 4965-4972.

Cantor, K. P., Blair, G., Everett, A., Gibson, R., Burmeister, L. F., Brown, L. M., et al. (1992). Pesticides and other agricultural risk factors for non-Hodgkin's lymphoma among men in Iowa and Minnesota. Cancer Res. 52, 2447-2455.

Crickmore, N., Zeigler, D. R., Schnepf, E., Van, R. J., Lereclus, D., Baum, J., et al. (2012). Bacillus thuringiensis Toxin Nomenclature. Available online at: http://www.lifesci.sussex.ac.uk/Home/Neil_Crickmore/Bt/

Crosa, J. H., and Falkow, S. (1981). "Plasmids," in Manual of Methods for General Bacteriology, eds P. Gerhardt, R. G. E. Murray, R. N. Costilow, E. W. Nester, W. A. Wood, N. R. Krieg, and G. B. Phillips (Washington, DC: American Society for Microbiology), 266-282.

Feitelson, J. S., Payne, J., and Kim, L. (1999). Bacillus thuringiensis: insects and beyond. Biotechnology 10, 271-275. doi: 10.1038/nbt0392-271

Flexner, J. L., and Belnavis, D. L. (1999). "Microbial insecticides," in Biological and Biotechnological Control of Insect Pests, eds J. E. Rechcigl and N. A. Rechcigl (Boca Raton, FL: Lewis Publishers), 35-62.

Gassmann, A. J., Petzold-Maxwell, J. L., Clifton, E. H., Dunbar, M. W., Hoffmann, A. M., Ingber, D. A., et al. (2014). Field-evolved resistance by western corn rootworm to multiple Bacillus thuringiensis toxins in transgenic maize. Proc. Natl. Acad. Sci. U.S.A. 111, 5141-5146. doi: 10.1073/pnas.1317179111

Ichikawa, M., Uemori, A., Yasutak, K., Kagoshima, K., Mizuki, E., and Ohba, M. (2008). Failure to phenotypically discriminate between non-insecticidal Bacillus thuringiensis strains with anticancer parasporins (PS2, PS3, and PS4) and Bacillus thuringiensis strains that produce insecticidal Cry proteins. Appl. Entomol. Zool. 43, 421-426. doi: 10.1303/aez.2008.421

Jackson, G. (1992). Agrochemical Usage in Asia Region: A Reference Compendium. Washington, DC: Asia Agriculture Technical Department, The World Bank.

Jouzani, G. S., Pourjan, A. A., Seifinejad, A., Marzban, R., Kariman, K., and Maleki, B. (2008). Distribution and diversity of Dipteran-specific cry and cyt genes in native Bacillus thuringiensis strains obtained from different ecosystems of Iran. J. Ind. Microbiol. Biotechnol. 35, 83-94. doi: 10.1007/s10295-0070269-6

Martin, P. A. W., and Travers, R. S. (1989). Worldwide abundance and distribution of Bacillus thuringiensis isolates. Appl. Environ. Microbiol. 55, 2437-2442.

Meisner, C., M., and Dasgupta, S., (2004). Identifying Pesticide Hotspots: the Case of Bangladesh. Mimeo. Available online at: http://www.worldbank/nipr

Pesatori, A. C., Sontag, J. M., Lubin, J. H., Consonni, D., and Blair, A. (1994). Cohort mortality and nested case-control study of lung cancer among structural pest control workers in Florida (United States). Cancer Causes Control 5, 310-318. doi: 10.1007/BF01804981

Ramaswamy, S. (1992). Pest Control and Environment. Notes for Discussion at a Seminar on Environment and Agriculture. Dhaka: Agriculturalist Association of Bangladesh.

Schnepf, E., Crickmore, N., Rie, V. J., Lereclus, D., Baum, J., Feitelson, J., et al. (1998). Bacillus thuringiensis and its pesticidal crystal proteins. Microbiol. Mol. Biol. Rev. 62, 775-806.

Shishir, A., Akter, A., Bodiuzzaman, Aktar, N., Rahman, M., Khan, S. A., et al. (2012). "Molecular characterization of indigenous Bacillus thuringiensis kurstaki isolates from Bangladesh and toxicity of Btk HD-73 against melon fruit fly, Bactrocera cucurbitae," in Paper Presented at the 1st AFSA Conferences on Food Safety and Food Security (Osaka).

The toxic action centre. (2012). Available online at: http://www.toxicsaction.org/ problems-and-solutions/pesticides

Travers, R. S., Martin, P. A. W., Reichelderfer, C. F. (1987). Selective process for efficient isolation of soil Bacillus spp. Appl. Environ. Microbiol. 56, 1263-1266.

WHO. (1992). Our Planet, Our Health: Report of the WHO Commission on Health and Environment. (Geneva: World Health Organization).

Wiles, R., and Campbell, C. (1994). Washed, Peeled-Contaminated: Pesticide Residues in Ready-To-Eat Fruits and Vegetables. (Washington, DC: Environmental Working Group).

Zahm, S. H., Weisenburger, D. D., Babbitt, P. A., Saal, R. C., Vaught, J. B., Cantor, K. P., et al. (1990). A case-control study of non-Hodgkin's lymphoma and the herbicide 2,4-dichlorophenoxyacetic acid (2,4-D) in Eastern Nebraska. Epidemiology 1, 349-356. doi: 10.1097/00001648-199009000-00004

Conflict of Interest Statement: The authors declare that the research was conducted in the absence of any commercial or financial relationships that could be construed as a potential conflict of interest.

Received: 06 March 2014; accepted: 23 May 2014; published online: 12 June 2014. Citation: Shishir A, Roy A, Islam N, Rahman A, Khan SN and Hoq MM (2014) Abundance and diversity of Bacillus thuringiensis in Bangladesh and their cry genes profile. Front. Environ. Sci. 2:20. doi: 10.3389/fenvs.2014.00020

This article was submitted to Environmental Health, a section of the journal Frontiers in Environmental Science.

Copyright (c) 2014 Shishir, Roy, Islam, Rahman, Khan and Hoq. This is an openaccess article distributed under the terms of the Creative Commons Attribution License (CC BY). The use, distribution or reproduction in other forums is permitted, provided the original author(s) or licensor are credited and that the original publication in this journal is cited, in accordance with accepted academic practice. No use, distribution or reproduction is permitted which does not comply with these terms. 